\title{
Comparative Analysis of EU and Kenyan Responses to Somali Piracy: A Leadership Perspective
}

\author{
Linganaden Murday*
}

\begin{abstract}
This article uses a leadership as process framework to examine the degree of mutuality that existed between EU and Kenyan responses to Somali piracy between roughly 2008 and 2012. In so doing, it seeks to comprehend whether regional and extra-regional actors had similar experiences of and responses to the situation. This is important because the voices of regional actors are largely marginalised and implicitly subsumed to those of more powerful global actors. This article focuses on the EU (as an extra-regional actor) and Kenya (as a regional actor). It undertakes an analysis of official and nonofficial documents available in the public domain to understand the interactions and exchanges of influence that underpinned the crafting and implementation of counter piracy measures. Overall, the article concludes that the EU and Kenya had different experiences of the piracy threats which then led to them each having different sets of priorities. On paper there seems to be mutuality between the EU and Kenya concerning the naval response: the need to solve the problem on land in Somalia and capacity building in the region. However, an analysis of interactions surrounding their counterpiracy measures reveals a more complex picture of discords. This article shows that, in fact, there was a low degree of mutuality between EU and Kenya in their responses to Somali piracy which hindered the formation of a strong common response incorporating regional and extra-regional actors.
\end{abstract}

\section{Introduction}

The recent surges of maritime piracy and armed robbery off the coast of Somalia and in the Gulf of Guinea have projected Africa as a hotbed of this major maritime security threat. ${ }^{1}$ This paper, however, focuses on Somali piracy because, unlike the Gulf of Guinea, it has affected Sea Lines of Communication (SLOCs) that are vital for world trade which consequently spurred an unprecedented international response. ${ }^{2}$ Focusing on the cases of the European Union (EU) and Kenya, it looks at the ways that regional and extra-regional actors defined and responded to piracy off the coast of Somalia at the height of the threat between roughly 2008 and 2012. The key

\footnotetext{
${ }^{1}$ Oceans Beyond Piracy (2014), The State of Maritime Piracy 2014: Assessing the Economic and Human Cost (Denver: One Earth Future Foundation)

2 Kamal-Deen, Ali (2015), Maritime Security Cooperation in the Gulf of Guinea: Prospects and Challenges (Leiden: Brill Nijhoff), p. 300
} 
question that this paper tries to answer is: What degree of mutuality existed between EU and Kenyan responses to Somali piracy? In answering this question, this paper uses a leadership as process framework which combines definitions of a given situation with an analysis of interactive processes underpinning the construction and implementation of measures to deal with that situation. Overall, this paper shows that there was a low degree of mutuality between the EU and Kenyan responses to Somali piracy. It claims that differences in the ways that Kenya and the EU experienced and articulated the piracy problem generated resistances and contestations over the type of response to be prioritised, thereby undermining the emergence of a solid unified front to deal with the Somali piracy problem in its multidimensionality.

In so doing, this paper seeks to challenge the existing literature that has emphasised western experiences and responses to Somali piracy and considered those of regional states as merely epiphenomenal. A case in point is Van Ginkel and Van der Putten's edited book. One of the key questions that work seeks to answer is 'how do the many nationalities involved [in counter-piracy] interact with one another?'3 Yet, the 'many nationalities involved' included mainly the global north. There are only passing observations on the role of regional state actors like Kenya, ${ }^{4}$ rather than chapters that fully detail their responses. The absence of this muchneeded regional perspective is somewhat unsurprising given that all the 'experts' contributing to the book are from the West.

In contrast, Gottlieb gave more attention to the regional responses. For him, initially, the international community led the counter-piracy efforts. ${ }^{5}$ Gradually, however, its role became more supportive as it assisted regional states to shoulder their maritime security responsibilities through capacity building. ${ }^{6}$ Overall, Gottlieb points out that the responses to Somali piracy followed a top-down approach flowing from the international community to regional states. ${ }^{7}$ However, this view is reductionist and fails to acknowledge the active role that states in the region played in crafting and

\footnotetext{
${ }^{3}$ Van Ginkel, Bibi and Van der Putten, Frans-Paul (2010), 'Introduction: The International Responses to Somali Piracy', in Van Ginkel, Bibi and Van der Putten, Frans-Paul (Eds) (2010), The International Response to Somali Piracy: Challenges and Opportunities (Leiden: Martinus Nijhoff Publishers), p. 8

${ }^{4}$ See for example: Homan, Kees and Kamerling, Susanne (2010) 'Operational Challenges to Counterpiracy Operations Off the Coast of Somalia', in Van Ginkel, Bibi and Van der Putten, Frans-Paul (Eds) (2010), op.cit., p. 76

${ }^{5}$ Gottlieb, Yaron (2015), 'Responding to Maritime Piracy: The Regional Approach',

University of Sanfranscisco Maritime Law Journal, 28(1), p. 16

6 Ibid., p. 31

7 Ibid., p. 16
} 
implementing anti-piracy measures. Gottlieb also fails to problematise the international assistance provided under the capacity building umbrella. Finally, his implicit assumption of mutuality of interest between the global and regional actors is questionable.

In contrast to the above, this paper uses the leadership as process framework to incorporate regional voices into the analysis of the piracy problem. One justification for using the leadership lens is the wicked character of the piracy problem. Leadership scholars like Grint distinguish between tame and wicked problems. ${ }^{8}$ Tame problems are those recurrent problems with predetermined, standard solutions that are amenable to managerial approaches. ${ }^{9}$ In contrast, wicked problems require leadership. ${ }^{10}$ These problems are so ubiquitous that they involve multiple people, departments and institutions. ${ }^{11}$ There are no predetermined solutions to wicked problems. Rather, they require creative solutions which normally generate their own problems. ${ }^{12}$ The complexity of wicked problems leads to a need for collaborative processes. ${ }^{13}$ Piracy bears the hallmark of a wicked problem because it impacted on several sectors including the tourism and fishing industries. ${ }^{14}$ Furthermore, as it will become clear in the next two sections, the collaborative solutions applied to the Somali piracy problem - which ranged from naval and judicial responses to dealing with lawlessness in Somalia - created their own problems.

To-date, leadership literature has dealt mainly with individuals evolving in the western corporate context. As such, there might be objections to applying its theories to international studies. Yet, the current trend in leadership studies is to move onto processes rather than individuals or positions. As Burns observes: 'Surely it is time... that the study of leadership be lifted out of the anecdotal and the eulogistic and placed squarely in the structure and processes of human development and political action'.15 Treating leadership as process widens the application of leadership studies.

\footnotetext{
8 Grint, Keith (2010), Leadership: A Very Short Introduction (New York: Oxford University Press), Chapter 2

${ }^{9}$ Ibid., p. 61

10 Ibid., Chapter 2

11 Ibid., p. 65

12 Grint, Keith (2008), Leadership, Management and Command: Rethink D-Day (New York:

Palgrave Macmillan), p. 11

13 Ibid.

14 The World Bank (2013), The Pirates of Somalia: Ending the Threat, Rebuilding a Nation (Washington: The World Bank), pp. xxiii and 57

15 Burns, James Macgregor (2012), Leadership (New York: Open Road Integrated Media), p. 25
} 
It, thus, becomes available to study the collaborative processes that are necessary to devise and implement counter-piracy measures.

To answer the key research question, this paper adopts a qualitative approach because it is more appropriate for tasks that try to capture the complexity of a given situation. ${ }^{16}$ There are many reasons that motivate the selection of the EU and Kenya for an in-depth inquiry. The EU had a bigger naval force and a more long-term mission in the region affected by Somali piracy than other extra-regional actors. ${ }^{17}$ Furthermore, compared to other actors, the EU has a more comprehensive programme to respond to piracy and takes on board a broad range of actors including non-state ones. ${ }^{18}$ Kenya is an interesting regional actor because its security is intrinsically linked to Somalia due to their shared borders and it has been a key player in the Somali conflict. ${ }^{19}$ Furthermore, it was the economic and military powerhouse of East Africa at that time and as such was bound to have the resources to exercise meaningful influence over the piracy situation..$^{20}$ This is testified by the fact that Kenya led the judicial response against Somali pirates. $^{21}$

There is a range of documents from governmental, inter-governmental and non-governmental sources that are available for analysis including newspapers articles, reports, speeches, resolutions and parliamentary debates. These documents constitute useful sources of information to understand the various responses to piracy and the international interactions that occurred in the process. However, records of interactions in minutes of meetings within international organisations or governments are not in the public domain. Attempts have been made to attenuate this limitation by using WikiLeaks documents. Future research on the topic may

\footnotetext{
${ }^{16}$ Creswell, John (2014), Research Design: Qualitative, Quantitative and Mixed Methods Approaches (London: Sage), p. 4

17 Gunther, Enrico, (2015), The European Union's Response to Piracy: Are the Lessons Learned in the Horn of Africa a Model for the Gulf of Guinea?, EU Diplomacy Paper 07/2015; Riddervold, Marianne (2014), 'New Threats- Different Response: EU and NATO and Somali Piracy', European Security, 23(4), p. 547; Bueger, Christian (2013), 'In Search for a Mission? The EU's Regional Training Mission EUCAP NESTOR', Piracy-Studies.Org, 18 October

${ }^{18}$ House of Lords (2010), Combating Somali Piracy: The EU's Naval Operation Atalanta, European Union Committee, $12^{\text {th }}$ Report of Session 2009-10, p. 39

${ }^{19}$ Bachmann, Jan (2012), 'Kenya and International Security: Enabling Globalisation, Stabilising 'Stateness', and Deploying Enforcement', Globalizations, 9(1), pp. 125-143 ${ }^{20}$ Kimenyi, Mwangi and Kibe, Josephine (2014), 'Africa's Powerhouse', Brookings, 06 January; Kruger, Anton and Martin, Guy (2013), 'Kenya Defence Forces', DefenceWeb, 09 July

${ }^{21}$ Eckhardt, Karl (2012),'Deterring Piracy through Prosecution', in University of Washington (2012), Task Force 2012: The Challenge of Piracy Off the Horn of Africa (Seattle: University of Washington), p. 43
} 
consider interviews to gather finer details on the processes surrounding the formulation and implementation of responses to piracy especially in Kenya where there is a lack of official documents in the public domain.

Having set the basic premises above, the rest of this paper is divided into four parts. The first section elaborates on the theoretical framework. The second and third sections then successively analyse the EU and Kenya experiences of and responses to piracy. The final part juxtaposes the findings from these two contexts and seeks to determine the degree of mutuality between their responses. A conclusion then follows. The paper ultimately helps show a low degree of mutuality between the EU and Kenya both in their experience and articulation of the problem, translating into a similarly low degree of mutuality in the responses that they prioritised. This is reflected in Kenya's emphasis on a land-based response geared towards improving its capacity as a regional state and mounting a creative response in Somalia while the EU displayed more attention and urgency to tackling the problem in the maritime realm. The clashes produced by this difference stultified the development of a strong common response encompassing regional and extra-regional actors.

\section{Theoretical Framework}

The leadership as process approach focuses on how leaders and followers relate to each other to achieve a mutual purpose within a given context. For Pierce and Newstrom, the leadership as process framework involves five elements: leader, followers, context (situation), the leadership process and the outcomes. ${ }^{22}$ Leader, followers and context are fundamental for the leadership process whereas outcomes are emanations of the process. Murphy defines process as 'the interplay of factors in a total situation'.23 Pierce and Newstrom adopt a similar understanding of leadership process but their definition is more useful as it contains examples of its constitutive elements. For them, process includes 'leading and following, as well as the assumption and surrender of power to define the situation, the provision of guidance toward goal attainment, exchanges, the building of relationships $[\ldots]$ and so on'. ${ }^{24}$ Overall, leadership as process captures the complexity of the leadership phenomenon.

\footnotetext{
22 Pierce, Jon and Newstrom, John (2011), Leaders and the Leadership Process (New York: McGraw-Hill), pp. 5-6

${ }^{23}$ Murphy, Albert (1941), 'A Study of the Leadership Process', American Sociological Review, 6(5), p. 674

${ }^{24}$ Pierce and Newstrom (2011), p. 6
} 
The situation provides the entry point for analysing the leadership process. According to Murphy, the situation determines who emerges as leader. ${ }^{25}$ Smircich and Morgan further entrench the importance of situation in leadership. Leadership, for them, involves defining the situation in a way that is meaningful to the group. Defining the situation then acts as a basis for organising collective actions. Through speeches and actions that speak to the broader experience of the group, leaders provide focal points in situations that are usually complex and ambiguous. ${ }^{26}$

Within a given context, both leaders and followers contribute to leadership. As Rost puts it: ' $[\mathrm{b}]$ oth leaders and followers form one relationship that is leadership'.27 The specificity of leadership as a process is that all proponents envisage an active role for followers. Pierce and Newstrom envisage a 'dynamic and interactive' relationship between leader and followers whereby they have the capacity to influence each other. ${ }^{28}$ Some even envisage the possibility that followers take leadership roles. ${ }^{29}$ As Murphy observes: '... the same individual alternates between leading and following depending on the situation'.30

The mutuality that holds the relations between leaders and followers together is also a vital element of leadership. ${ }^{31}$ In essence, mutuality means 'a sense of shared feelings or intentions among people experiencing a particular situation'.32 In underlining its importance, Burns argues that leadership involves a person with resources and motives, using those resources to stimulate respondents holding similar motives into realising a mutual purpose. ${ }^{33}$ The leader takes the initiative to make connection with the followers but if the followers take the initiative, they assume a leadership role. ${ }^{34}$ In the same vein, Rost notes that mutuality is developed within the 'influence relationship' between leaders and followers. ${ }^{35}$ The mutual purposes developed in that interaction may change over time

\footnotetext{
25 Murphy (1941), pp. 674-687

${ }^{26}$ Smircich, Linda and Morgan, Gareth (1982), 'Leadership: The Management of Meaning', The Journal of Applied Behavioral Science, 18(3), pp. 257-273

${ }^{27}$ Rost, Joseph (1993), Leadership for the Twenty-First Century (London: Praeger), p. 109

28 Pierce and Newstrom (2011), p. 6

${ }^{29}$ See for example Northouse, Peter (2013), Leadership: Theory and Practice (London:

Sage), p. 8

30 Murphy (1941), p. 674; Rost (1993), p. 112

31 Burns (2012), p. 56

32 Olonisakin, 'Funmi (2017), 'Towards Re-conceptualising Leadership for Sustainable

Peace', Leadership and Developing Societies, 2(1), p. 20

33 Burns (2012), p. 54

34 Ibid., p. 59

35 Rost (1993), pp. 103, 120 and 123
} 
depending on the situation. Moreover, for Rost, the fluidity of intentions means that it is possible to have a gradual change in purposes. ${ }^{36}$

Exercising influence itself is based on power. ${ }^{37}$ However, there is no agreement among leadership scholars on what constitutes power. This is unsurprising given the contingent character of the concept. French and Raven identify five social bases of power, namely reward, coercive, legitimate, referent and expert powers. ${ }^{38}$ In brief, reward power is based on the power to distribute rewards ${ }^{39}$ while coercive power concerns the ability to punish. ${ }^{40}$ French and Raven consider legitimate power as 'the most complex' element of power and can stem from formal position as well as informal sources arising from social interactions ${ }^{41}$ Legitimate power can be acquired by occupying a position in a given hierarchy within an organisations. ${ }^{42}$ More informally, legitimate power can be derived from behaving according to prevailing norms and values. ${ }^{43}$ It can also emanate from expectations of reciprocity whereby one's socially valued actions is usually accompanied by the expectations of similar actions from receivers. ${ }^{44}$ Referent power is power mustered by being likeable and attractive to others. ${ }^{45}$ Expert power is derived from being knowledgeable. ${ }^{46}$ French later added informational power to the list. It is essentially the power that one derive from ability to present information and logical arguments. ${ }^{47}$

In contrast to this systematic classification, Burns defines power resources very broadly to include economic power, military power and institutional power, amongst others. ${ }^{48}$ Furthermore, for him what constitutes power depends on cultures and situations. ${ }^{49}$ Similarly, Rost identifies a broad range of power resources including reputation, prestige and 'give- and -take

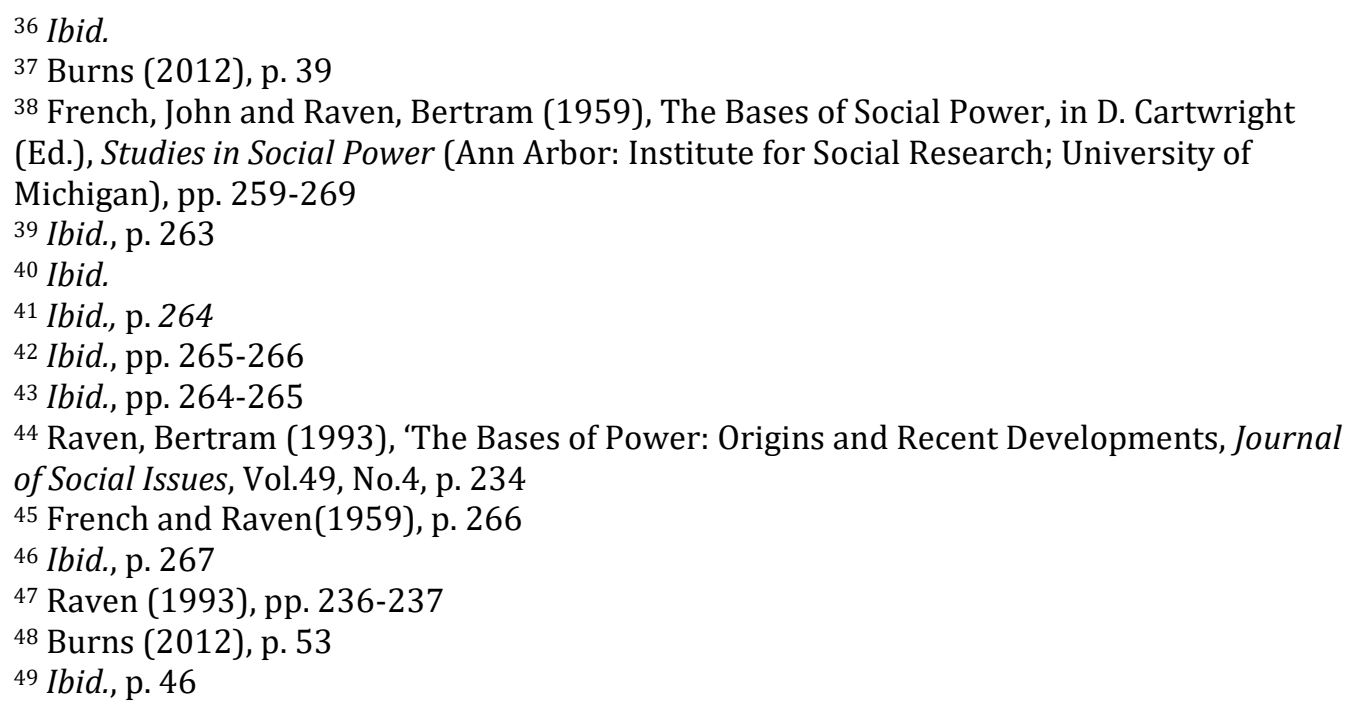


behaviours'. ${ }^{50}$ However, these classifications are not mutually exclusive. For example, reward power overlaps with 'give-and-take behaviours'. Therefore, this article draws from all these definitions of power to give a glimpse of the resources that EU and Kenya used in the process of developing mutuality to mount responses against Somali pirates.

\section{EU's Responses to Piracy}

EU responses were characterised by its comprehensive approach to counterpiracy. The EU Maritime Security Centre Horn of Africa (MSCHOA) for example, claimed that ' $\mathrm{t}$ ] ogether EUNAVFOR [European Union Naval Force Somalia], EUCAP NESTOR [EU Regional Capacity Building Mission in the Horn of Africa] and EUTM [European Union Training Mission] form a coherent, integrated CSDP [Common Security and Defence Policy] package...' 51 These initiatives involved building relationships within the EU as well as between the EU and a broad range of other actors. However the quality of relationships built differed from one component to another. The EU was more creative and interactive in its naval response than in its initiatives on capacity building in the region or the stabilisation of Somalia.

EU officials generally emphasised the economic importance of the maritime realm when referring to their specific interests in combating piracy. The European Commissioner for Maritime Affairs and Fisheries, for example, emphasised the EU's dependence on the maritime realm- reflected in its $€ 500$ billion blue economy that employed some 5.6 million people. ${ }^{52}$ More broadly, piracy threatened the 95 percent (by volume) of EU trade transported by sea. ${ }^{53}$ Trade itself was dependent on the shipping industry in which the EU was a world leader. ${ }^{54}$ Unsurprisingly, these articulations of the situation reflected the interest of its members. As the UK's Foreign Office Minister bluntly put it:

'The British shipping industry is a vital part of both our economy and society- employing over 48,000 citizens and turning over in excess of $€ 12$

\footnotetext{
${ }^{50}$ Rost (1993), p. 105

51 MSCHOA (2016), About MSCHOA and OP ATALANTA

52 Damanaki, Maria (2013), Speech: Maritime Piracy: Continuing the Fight, 23 January

${ }^{53}$ European Union External Action (2018a), MSCHOA; Brunnstrom, David (2008), 'EU Launches Somalia Anti-Piracy Operation', Reuters, 08 December

54 European Community Shipowners' Associations (N.d), The European Shipping Industry in a Nutshell, (Brussel: ECSA)
} 
billion. It is the Government's responsibility to promote and protect UK shipping interests, and the space in which they operate'. 55

However, the nexus between instability in Somalia and piracy off its coast was also widely recognised, especially as from 2009 when signs of success from the naval operations in the Gulf of Aden opened the space for a more comprehensive articulation of the problem. ${ }^{56}$ In the broader region, Admiral Hudson (Operational Commander of EUNAVFOR) pointed out that the lack of regional coast guard capacity also allowed piracy to flourish. ${ }^{57}$

In the above situation, the EU drew from several power resources to exercise influence and build relationships to change the situation. These included their expertise and experience in the maritime realm as well as their military, political and economic resources. ${ }^{58}$ The priority area of the EU was dealing with piracy at sea through Operation Atalanta (EUNAVFOR). This involved building relations within the EU and between the EU and other actors such as the shipping industry, Kenya and other naval coalitions.

EU member states had to be persuaded to create a new naval coalition instead of joining North Atlantic Treaty Organisation (NATO) operations. The process was initiated by France which took the presidency of the EU in mid-2008.59 Drawing from documents and interviews, Riddervold found that EU members were persuaded to create EUNAVFOR based on the legitimacy of the French proposal. ${ }^{60}$ An interactive process of mutually assessing each other's arguments on the proposal culminated in EU members accepting the creation of EUNAVFOR. Interestingly, the agreement that allowed pirates captured during naval operations to be tried in a third country (Kenya) in accordance with a certain standard of justice was the key to convincing EU members. ${ }^{61}$ This is because EU members were reluctant to try suspected pirates in their jurisdictions as they could become eligible for asylum. ${ }^{62}$

\footnotetext{
55 Burt, Alistair (2013), Speech: International Action Against Piracy, 21 January; House of Lords (2010), p. 7

56 Solana, Javier (2009a), 'Mobilise Now to Stabilise Somalia', The Guardian, 12 August

${ }^{57}$ House of Lords (2010), p. 18

58 Lidington, David (2012), Speech: EU Common Security and Defence Policy: The UK

Perspective, 27 June

${ }^{59}$ Riddervold (2014), pp. 549 and 554

60 Ibid., pp. 546-564

61 Ibid., pp. 555-558

62 Otto, Lisa (2012), Situation Report: Kenya and the Pest of Piracy, Institute for Security

Studies, 22 February, p. 4
} 
Apart from the agreement of its members, the EU also derived legitimacy from United Nations Security Council (UNSC) resolutions that called for a naval response. ${ }^{63}$ This legitimate power was further enhanced by the altruistic terms in which EUNAVFOR's mandate was couched by including the protection of World Food Programme (WFP) ships and improving regional capacity, although the exact nature of that intended improvement was unspecified. ${ }^{64}$ This altruism also conferred referent power to the EU. At the operational level, UK emerged as the leader in EU's maritime response because of expert power derived from its status as the centre of the global maritime industry ${ }^{65}$ and its widely respected navy. ${ }^{66}$ However, EU members could participate in decision making on the operations because of the 'flat' nature of the command structure of EUNAVFOR which gave all EU member states an institutionalised voice in decision making processes. ${ }^{67}$ This horizontal feature expedited decision making which partly explains the effectiveness of EUNAVFOR. ${ }^{68}$ This horizontality seems to have ensured that information, concerns and inputs could be more readily shared, discussed and implemented compared to going through tortuous hierarchical channels. Thus, while UK was officially the leader, other members of the EU also contributed in that leadership. Overall, there is a general agreement that EUNAVFOR was successful in its endeavour to curb piracy and has contributed significantly in the substantial decline in piracy from 176 incidents in 2011 to 4 in $2018 .{ }^{69}$

However, the sheer size of the area affected by piracy constituted an immense operational challenge. ${ }^{70}$ Consequently, it became important to build relations with other actors pursuing similar aims. In that realm, the US initiated the Shared Awareness and Deconfliction (SHADE) to coordinate the operations of the three main coalitions involved in anti-piracy operations..$^{71}$ SHADE had a rotating leadership shared between EU, NATO and Combined Maritime Force (CMF) which were all pursuing similar aims.

\footnotetext{
63 EUNAVFOR Somalia (2018), 'Mandate', European Union External Action

64 Ibid.

65 Daniels, Christopher (2012), Somali Piracy and Terrorism in the Horn of Africa, (Lanham: The Scarecrow Press), p.37; House of Lords (2010), p. 9

${ }^{66}$ House of Lords (2010), p. 9

67 Ibid., p. 39

68 Ibid.

${ }^{69}$ House of Lords (2012), Turning the Tide on Piracy, Building Somalia's Future: Follow-up Report on the EU'S Operation Atalanta and Beyond, European Union Committee: $3^{\text {rd }}$ Report of Session 2012-13, p. 10; European Union External Action (2018b), 'EU NAVFOR Atalanta: 10 Years of Fighting Piracy in Somalia', Press Release, 08 December; World Maritime News (2018), 'EU's Anti-Piracy Operation Gets Extension', 03 August

${ }^{70}$ Homan and Kamerling (2010), pp. 68-69

${ }^{71}$ Ghosh, P.K. (2016), 'Shared Awareness and Deconfliction Initiative', Indo-Pacific

Defense Forum, 23 February
} 
It became a platform for regular interaction and exchange of influence as participants shared information, exchanged views and coordinated their activities. $^{72}$

The EU also interacted directly with the shipping industry. The common power resources at the basis of the exchange of influence between the EU and the shipping industry included informational and expert powers. The regular meetings between industry representatives and EUNAVFOR command ${ }^{73}$ became spaces to maintain briefs and frank exchanges of views' ${ }^{74}$ The symbol of that close relationship was the novel initiative to establish the MSCHOA in the EUNAVFOR headquarters in the UK in 2009.75 The MSCHOA was at the basis of several innovative solutions. For example, it ran a website that fostered interaction between the shipping industry and EUNAVFOR. Ships that passed through the Gulf of Aden were strongly advised to register on the MSCHOA website prior to their passage. In turn, MSCHOA provided updated security information on the Gulf of Aden ${ }^{76}$ and advised crews on the best practices to reduce the risk of attacks. ${ }^{77}$ Furthermore, information about transiting vessels was shared with other actors like NATO and CMF to enhance the efficiency of naval operations. ${ }^{78}$ Overall the MSCHOA initiative was considered to be 'highly effective' by the Chamber of Shipping. ${ }^{79}$

\section{Empowering Regional Actors}

Capacity building in the region relied substantially on EU's expert, economic and military powers. Initially the EU focused on assistance to ease the prosecution and detention of suspected pirates (see discussion in the next section). It later turned its attention towards capacity building in maritime security to reduce the 'burden on European naval forces'. ${ }^{80}$ This endeavour was further enhanced in 2012 with the creation of EUCAP NESTOR which

\footnotetext{
72 Oceans Beyond Piracy (N.d.), Shared Awareness and Deconfliction

${ }^{73}$ European Union External Action (2010), 'Piracy Threat and Merchant Industry', 14 October

${ }^{74}$ Ibid.

75 European Union External Action (2018a); Smith, Michael (2017), Europe's Common Security and Defence Policy: Capacity- Building, Experiential Learning, and Institutional Change, (Cambridge: Cambridge University Press), Chapter 6

76 The European Commission (2010), Commission Recommendation of 11 March 2010 on Measures for Self-Protection and the Prevention of Piracy and Armed Robbery Against Ships, 2010/159/EU, Para 8

77 House of Lords (2010), pp. 15-16

78 Muratore, Andrew (2010), 'EU-NATO Co-operation and the Pirates of the Gulf of Aden', Australian Journal of Maritime and Ocean Affairs, 2(3), p. 98

${ }^{79}$ House of Lords (2012), p. 11

80 US Mission to European Union (2009), 'EU Developing Comprehensive Approach to Fighting Piracy', Wikileaks cable 09Brussels878_a, 25 June
} 
aimed at building capacity in countries like Kenya and Somalia. ${ }^{81}$ EUCAP NESTOR had ten different objectives that were mostly geared towards the software aspect of capacity building like building domestic legislations or training coast guard officers. ${ }^{82}$

However, there were concerns about the EU's commitment to capacity building in the region. EUCAP NESTOR failed to coordinate its programme with those of other organisations like the United Nations Office on Drugs and Crime (UNODC) which led to duplications in the trainings that were dispensed, for instance. ${ }^{83}$ Even worse, the mission was understaffed and lacked the necessary expertise to achieve its objective. ${ }^{84}$ More importantly, EUCAP NESTOR had a top-down approach to capacity building. ${ }^{85}$ Rather than engaging the local authorities to understand their needs, the EU elaborated projects that reflected its interests and tried to get them accepted by targeted states.86 As a result, it failed to understand and respond to the maritime security needs of states in the region. Kenya and Tanzania, for instance, refused to participate because they had already acquired expertise and skills from programmes run by organisations like UNODC and instead needed equipment for their coastguard and navy. ${ }^{87}$ Furthermore, EUCAP NESTOR was crippled by excessive bureaucracy in Brussels (where it was managed) which caused serious delays and undermined local trust in the mission. ${ }^{88}$ Overall, unsurprisingly, as the European Scrutiny Committee explained: 'EUCAP NESTOR failed to make any discernible impact and suffered particularly from a lack of partner "buy in". 89

\section{EU in Somalia}

The EU also tried to stabilise Somalia by collaborating with actors like the Transitional Federal Government (TFG), US and the African Union Mission in Somalia (AMISOM). Its initiatives concerned mainly the building of institutions of a centralised state by taking the TFG as the foundation. It launched the EUTM in 2010 with a one-year renewable mandate that

\footnotetext{
${ }^{81}$ Council Decision 2012/389/CFSP, 16 July 2012

82 Ibid.

83 Bueger (2013)

84 Ibid.

85 Ejdus, Filip (2017), “"Here is Your Mission, Now Own It!” The Rhetoric and Practice of

Local Ownership in EU Interventions', European Security, 26(4), pp. 470-484

86 Ibid., pp. 470-471

87 Bueger (2013)

${ }^{88}$ Ejdus (2017), p. 471

89 European Scrutiny Committee (2015a), Regional Maritime Capacity Building in the Horn of Africa (EUCAP NESTOR), 14 October
} 
evolved over the years but remained centred on strengthening the TFG through the training of its defence forces. ${ }^{90}$ Within the EU, the mission was spearheaded by Spain (one of the EU major maritime powers) but it also received the external support of the US and Uganda ${ }^{91}$ Headquartered in Uganda, EUTM became the training arm of the $2007 \mathrm{EU}$ supported AMISOM initiative. AMISOM is a UN approved regional peacekeeping mission operating under the aegis of the African Union and whose main aim was to support the TFG. ${ }^{92}$ The two programmes were also linked because AMISOM worked with the Somali soldiers, trained by EUTM, in order to set up the premises of a Somali National Army. ${ }^{93}$ Apart from its military and economic power, the EU based its action on legitimate power associated with UNSC resolutions like Resolution 1872 urging member states to provide training and equipment to Somali security forces. ${ }^{94}$ It also relied on its reputation as a world leader in security sector reform. ${ }^{95}$

However, EU's initiatives to stabilise Somalia were questionable not only in terms of quality of the programmes implemented but also the very idea that underpinned them. Even if by 2012, it had trained more than 1800 Somali soldiers and contributed in improving the professionalisation of the Somali security forces, ${ }^{96}$ EUTM suffered from issues like lack of protection force to ensure that the mission could operate without fear of asymmetric attacks. ${ }^{97}$ Furthermore, the soldiers of the nascent Somali national army owed their allegiance to their clan rather than the federal government. ${ }^{98}$ Concerning AMISOM, EU's assistance has been found to be 'half hearted' as it lacked funding, personnel and equipment to carry out its mission. ${ }^{99}$ Unsurprisingly, the overall assessment of EUTM, deemed its contribution in improving the security environment in Somalia as 'relatively modest'.100 Similarly, AMISOM has enjoyed some successes in fighting Al-Shabaab but

\footnotetext{
90 Council Decision 2010/96/CFSP, 15 February 2010, Article 1

91 Oksamytna, Kseniya (2011a), 'The European Union Training Mission in Somalia: lessons Learnt for EU Security Sector Reform', IAI Working Papers 11, 16 June, pp. 5-8 ${ }^{92}$ AMISOM (2018), Frequently Asked Questions

93 Oksamytna, Kseniya (2011b), 'The European Union Training Mission in Somalia and the Limits of Liberal Peacebuilding: Can EUTM Contribute to Sustainable and Inclusive Peace?', The International Spectator, 46(4), p. 102

${ }^{94}$ Council Decision 2010/96/CFSP, op.cit., part (1)

95 Oksamytna (2011a), p. 1

${ }^{96}$ House of Lords (2012), p. 21

${ }_{97}$ European Scrutiny Committee (2015b), EU Military Mission to Contribute to the Training of Somali Security Forces (EUTM), 25 February

98 Williams, Paul (2016), 'AMISOM Under Review', The RUSI Journal, 161(1), p. 46

99 Vines, Alex (2010), 'Rhetoric From Brussels and Reality on the Ground: the EU and Security in Africa', International Affairs, Vol. 86, No.5, p.1099; Williams (2016), p. 45 100 European Scrutiny Committee (2015b)
} 
expectations that it could stabilise Somalia was deemed to be highly overrated. ${ }^{101}$

The EU's approach to strengthen a deeply unpopular TFG, whose leadership was described by the UN as lacking 'vision or cohesion',102 was also troubling. Above all, within EU itself it was recognised that the lack of political will of the TFG was an obstacle to the success of programmes like EUTM. ${ }^{103}$ Yet, EU's persistence with the TFG can be explained by its longstanding attempts to reproduce western understandings of the state in non-western contexts to promote stability. As Oksamytna observes: '[l]ike most other post-conflict peacebuilding endeavours, EUTM Somalia is an attempt to reconstruct Somalia as a centralised, rational, modern bureaucratic state'.104 In other words, EU's actions in Somalia resembled the traditional externally driven, top-down liberal peacebuilding approach. ${ }^{105}$ In so doing, the EU ignored many non-official local and regional entities, like the Ahlu Sunna Wal Jama'a (ASWJ), that were providing degrees of peace and security in Somalia. ${ }^{106}$ This served the purpose of the TFG which showed 'active resistance to engagement with or the empowerment of local, de facto political and military forces elsewhere in the country'.107 Consequently, one can reasonably argue that the focus on leaders in official positions (TFG) and lack of recognition and interaction with emergent leaders (local and regional authorities) contributed in weakening the impact of EU's initiatives.

Therefore, even if the EU had a comprehensive approach to countering Somali piracy on paper, it did not engage with each element with the same vigour, style and mindset. Its maritime response through EUNAVFOR was interactive and it showed a willingness to be inclusive and creative. This contrasts sharply with the regional capacity building and measures taken in Somalia. Within Somalia, for instance, EU failed to explore creative solutions as shown by its inability to look beyond the TFG and the construction of a centralised state. Although the EU is certainly not the only actor to be blamed for lack of progress in stability in Somalia, its lack of imagination in that particular component of its comprehensive program is striking.

\footnotetext{
101 Williams (2016), p.40; Vines (2010), p. 1099

102 Oksamytna, Kseniya (2011a), pp.6-7; UNSC (2010), Report of the Monitoring Group on Somalia and Eritrea Pursuant to Security Council Resolution 1916, p. 16

103 European Scrutiny Committee (2015b)

104 Oksamytna, Kseniya (2011b), p. 103

105 Stremlau, Nicole (2019), 'Governance Without Government in the Somali Territories', Columbia Journal of International Affairs, 09 January

106 Oksamytna, Kseniya (2011b), p. 104

107 UNSC (2010), p. 16
} 


\section{Kenya's Responses to Piracy}

'The Kenyan delegation made strong statements urging the international community to do more to combat piracy and indicated the GOK [Government of Kenya] was strongly committed to sharing the burden'.108

The above passage succinctly captures the nature of the relationship between Kenya and the international community with respect to the formulation and implementation of counter-piracy measures. More than just calling for help, it registered its intention to be an active participant in that collective response. This was the case when it took the lead to prosecute suspected pirates - an initiative that fed into the international naval response. It also actively engaged with its internal weaknesses that became more apparent with the piracy problem. Yet by indicating that it wanted the international community to do more, the quote also implicitly reveals Kenyan dissatisfaction with the international response. For instance, it expressed dissatisfaction with the lack of a more robust response on land in Somalia given that in the Kenyan context, the piracy problem wrapped into the gamut of threats emanating from lawlessness in Somalia to the extent that they became indistinguishable from one another in the public discourse.

There is a clear socio-economic aspect to the articulation of the problem in Kenya. The tourism industry suffered as the number of cruise ships arriving in Kenya declined considerably. ${ }^{109}$ Moreover, it laid bare the weaknesses of the Kenyan anti-money laundering laws as ransom money started to affect the Kenyan economy by inflating house prices. ${ }^{110}$ It increased the risk of using sea routes and the resultant rise in insurance cost made trade more expensive. ${ }^{111}$ It should be noted that 92 percent of Kenyan trade (by volume) is seaborne. ${ }^{112}$ Those in leadership positions, however, generally did not define the piracy problem as one that concerns the shipping

\footnotetext{
108 US Secretary of State (2008), 'Progress on US Counter-Piracy Agenda at International Piracy Conference', WikiLeaks Cable 08STATE134960_a dated 28 December 109 Hansard (2009a), Kenya Parliamentary Debates 3692, 11 November; Kagwe, Winfred and Kikhara, Githua (2011), 'Piracy Shoots Down Cruise Ships Numbers', Daily Nation, 19 January

110 Mayoyo, Patrick and Barasa, Lucas (2008), 'Piracy Off Somali Coast a Growing Global Headache', Daily Nation, 22 November ; Hansard (2009b), Kenya Parliamentary Debates 3674,10 November

111 Hansard (2009b)

112 Lakshmi, Aiswarya (2015), 'Kenya to Focus on Maritime Safety, Security', MarineLink, 24 February
} 
industry because no Kenyan ship had been hijacked by the pirates. ${ }^{113}$ In fact, Kenya only had a small shipping industry consisting of marine crafts rather than proper ships. ${ }^{114}$

More directly, piracy threatened the Kenyan mainland especially as from 2011, when there was increasing evidence of cooperation between AlShabaab and pirate groups as the former started to look for new ways to fund its activities. ${ }^{115}$ This coincided with attacks and abductions in the Kenyan coastal town of Lamu and fishing village of Malindi. ${ }^{116}$ These attacks were probably prompted by the success of the international naval operations and the measures taken by the shipping industry which forced the pirates to turn to 'softer targets'. ${ }^{117}$ This further fuelled the feeling that naval solutions were inadequate. However, officially Kenyan leaders attributed these attacks to Al-Shabaab rather than the pirates.

Following these attacks, the Minister of Internal Security posited that 'our territorial integrity is threatened'.118 However, rather than shaping the Kenyan definition of the situation, these events confirmed its initial articulation that emphasised the land aspect of the problem. In 2010, for instance, Prime Minister Raila Odinga claimed in parliament that: '... have told members of the international community recently that the war against piracy will be won on land because we must deal with this menace at source'.119 More interestingly, Odinga connected the piracy problem to instability in Somalia and the refugee problem that Kenya was facing. ${ }^{120}$ This denotes the point that for Kenyan leaders it was difficult to disentangle the various threats emanating from Somalia.

In terms of responses, domestically, Kenya built its capacity by strengthening its laws to deal with the impact of piracy. One example of this legal response is the enactment of The Proceeds of Crime and Anti-Money

\footnotetext{
113 Hansard (2009c), Kenya Parliamentary Debates 3695, 11 November

114 Beja, Patrick (2015), 'Kenya Poised to Attract Global Shipping Lines With Establishment of List', Standard Digital, 28 September

115 Saul, Jonathan and Reed, Camila (2011), 'Shabaab- Somali Pirate Links Growing: UN Adviser', Reuters, 20 October

116 Willsher, Kim (2011), 'Kidnapped French Woman Taken to Somalia by Pirates After Sea Battle', The Guardian, 01 October; Khalif, Abdul Kadir and Mwangi Nyassy Daniel (2011), 'Fury as Gang Abducts Fishermen in Malindi', Daily Nation, 20 November 117 Saul and Reed (2011)

118 Gettleman, Jeffrey (2011), 'Kenyan Forces Enter Somalia to Battle Militants', The New York Times, 16 October

119 Hansard (2010), Kenya National Assembly Official Report, 01 December; see also US Embassy Nairobi (2010), 'ASD Vershbow Visit Highlights Regional Security Issues', Wikileaks cable 10NAIROBI159_a , 11 February

120 Hansard (2010)
} 
Laundering Act (POCAMLA). It also passed the Merchant Shipping Act in 2009 to strengthen Kenyan jurisdiction over the prosecution of pirates. ${ }^{121}$ These domestic initiatives helped cement Kenya's image as a reliable actor in the fight against piracy. So much so that by 2012, the University of Washington was claiming that 'Kenya possesses one of the most comprehensive national piracy statutes in the world'. ${ }^{122}$

These domestic actions gave Kenya legitimate power by placing it more in line with the anti-piracy values and norms of the international society which gave it the authority to prosecute pirates. By the same token, Kenya became more attractive (referent power) as a partner in the struggle against piracy. This referent power was reinforced by the portrayal of its jurisdiction as one where suspected pirates would enjoy a fair trial.123 Kenya could also claim to have the knowledge and experience (expert power) derived from previous prosecutions of Somali pirates in 2006.124 Therefore Kenya drew from expert, referent and legitimate powers to lead the prosecutorial dimension of counterpiracy and stake claims on international assistance to build and equip its institutions in that regard. Kenya exercised influence during international conferences. For instance, in December 2008, Kenya jointly organised a conference on piracy with the UN during which its foreign minister proposed to sign an MoU with the US on the prosecution of pirates. ${ }^{125}$ It also signed MoUs with other actors like Canada, EU and China. In shouldering the burden of prosecution of pirates, Kenya sought to achieve both maritime and land-based purposes including reducing piracy which would in turn improve its maritime and port security, protect its tourism industry and more generally contribute in stabilising Somalia. ${ }^{126}$

However, there were also issues that undermined Kenya's bases of power. In 2008, the prison and detention facilities were described as 'harsh and life threatening' and 'overcrowded'.127 This is why Kenya called for its followers' (those who responded to its initiative) 'cooperation and assistance'. ${ }^{128}$ The claim for capacity building became inbuilt in Kenya's leadership in prosecution. It can also be argued that Kenya had legitimate

\footnotetext{
121 Gathii, James Thuo (2010), 'Kenya's Piracy Prosecutions', The American Journal of International Law, 104(3), p. 429

122 Eckhardt (2012), p. 44

123 BBC News (2010), 'Kenya Opens Fast-Track Piracy Court in Mombasa', 24 June

${ }^{124}$ Axe, David (2008), 'Somali Pirates Face Justice, Finally', Wired, 15 December

125 US Secretary of State (2008)

${ }^{126}$ Hansard (2009a)

127 Bureau of Democracy, Human Rights, and Labor (2009), Kenya: 2008 Country Reports on Human Rights Practices, US Department of State, 25 February

128 US Secretary of State (2008)
} 
power to claim reciprocity from beneficiaries of its leadership in prosecution. The EU-Kenya MoU, for instance, shows that the EU would provide 'technical support, expertise, training and other assistance upon request of Kenya ...'129 The EU also promised to assist Kenya in terms of investigation, prosecution and even handling of evidence. ${ }^{130}$ However, the MoU remained silent on the real amount of assistance that the EU was prepared to provide. Furthermore, there was no provision for regular meetings to review progress in implementing its provisions.

Yet, prosecution was an important element in the international response to Somali piracy as the failure of the international community to bring pirates to justice undermined the international naval response. ${ }^{131}$ In fact before the Kenyan initiative, those conducting the naval response to piracy, including EU members, generally released captured pirates back in Somalia mainly because of the complexity of prosecution and the possibility that they might eventually become eligible for political asylum. ${ }^{132}$ This catch and release policy made it less risky to engage in piracy leading to cases of recidivism. ${ }^{133}$ Therefore, Kenyan leadership in the prosecution of pirates was seen as an important element in counterpiracy. This is captured by Solana's remark during an EU meeting of Defence Ministers:

'The EU has an agreement with Kenya on the handover and prosecution of pirates. This will help greatly to improve the deterrent effect of the fight against piracy by demonstrating that pirates can no longer count on impunity'.134

However, by mid-2009, Kenya had lost enthusiasm for its leadership role in the prosecution of pirates. Suspected pirates were transferred to Kenya without proper consultation with the Kenyan authorities and with weak evidence on which to build court cases. ${ }^{135}$ Furthermore, the high number of suspected pirates brought to Kenya soon after the signature of the MoUs overwhelmed the Kenyan legal system. ${ }^{136}$ Overall, there was a feeling that

\footnotetext{
${ }^{129}$ EUR-Lex (2009), Exchange of Letters Between the European Union and the Government of Kenya, Document 22009A0325(01), Section 9(b)(6)

130 Ibid., Section 6

131 UNSC (2008), Resolution 1851, 16 December

132 Kraska, James and Wilson, Brian (2011), 'Combatting Piracy in International Waters', World Policy, 23 February

133 UNSC (2011), Report of the Special Adviser to the Secretary-General on Legal Issues

Related to Piracy off the Coast of Somalia, 24 January, p. 13

134 Solana, Javier (2009b), Informal Meeting of the Defence Ministers- Remark by Javier Solana, Prague, 12-13 March 2009

135 US Embassy Nairobi (2009a), 'Update on Kenyan Piracy Prosecutions', WikiLeaks cable 09NAIROBI1527_a 16 July

136 Ibid.
} 
Kenya had become a 'dumping ground' for pirates. ${ }^{137}$ Consequently, by September 2009, Kenya started to use threats of ending its role in the prosecution of pirates (coercive power) to influence actors like the EU and the US to provide more assistance. ${ }^{138}$

This seems to have spurred actions from the international community. ${ }^{139}$ In mid-2010, Kenya opened a court dedicated to trying suspected pirates in Mombasa. The $\$ 5$ million project was funded by international donors including the EU, Australia and Canada. ${ }^{140}$ This new court facility was also accompanied by a refurbishment of the Shimo la Tewa prison and assistance to the prosecutor's office. ${ }^{141}$ However, this reaction was deemed to be far from sufficient. ${ }^{142}$ Consequently, Kenya terminated the MoUs that it signed previously at the end of $2010 .{ }^{143}$

\section{Intervening in Somalia}

Generally, Kenya approached the Somali problem by supporting peace negotiations. ${ }^{144}$ It drove the Somali peace processes between 2002 and 2004 which led to the creation of the TFG. ${ }^{145}$ However, the attacks on its tourist resort, the failure of the TFG to stabilise Somalia and the growing influence of Al-Shabaab in southern Somalia contributed to a change in this approach. ${ }^{146}$ Most analysts blamed the attacks on Somali bandits and pirates yet the official discourses placed the responsibility squarely on AlShabaab. ${ }^{147}$ It is thus very likely that by attributing pirate attacks to AlShabaab (a land based threat), Kenya sought to steer international efforts towards the land which was more reflective of the Kenyan view and experience of the problem. This suggests that through their utterances and actions, Kenyan politicians tried to redefine the situation in a way that made

\footnotetext{
137 Menya, Walter (2010), 'Why Kenya Broke Deal on Piracy Trials', Daily Nation, 9 October

138 US Embassy Nairobi (2009b), 'Kenya Threatens End to Piracy Prosecutions', WikiLeaks cable 09NAIROBI2016_a, 24 September

139 BBC News (2010)

140 Ibid.

141 Ibid.

142 Ibid.

143 Leposo, Lillian (2010), 'Kenya Ends Agreement with EU to Prosecute Suspected Somali Pirates', CNN, 04 October; Menya (2010)

144 Miyandazi, Luckystar (2012), 'Kenya's Military Intervention in Somalia', Accord, 11

November

145 Menkhus, Ken (2012), After the Kenyan Intervention in Somalia, The Enough Project, January, p. 3

146 Ibid.

147 Gettleman (2011); Hansard (2012), Kenya National Assembly: Official Report, 23 May
} 
a land-based operation more meaningful as a focal point of international action.

Kenya unilaterally sent its troop to Somalia on 16 October 2011 in an operation dubbed Linda Nchi (Protect the Country). This action was based on military and legitimate powers. The military power emanated from its status as the most powerful defence force in East Africa. ${ }^{148}$ Its legitimate power was derived from Article 51 of the UN Charter on right to selfdefence. ${ }^{149}$ While incidentally, sending troops to Somalia provided a terrestrial dimension to counterpiracy, ${ }^{150}$ the purposes were couched in much broader terms. It ranged from defeating Al-Shabaab and securing borders ${ }^{151}$ to creating the necessary conditions for 'the voluntary return of Somalis to Somalia'.152

More interestingly, Kenya used the piracy-fuelled insecurity context to legitimise its pursuit of the Jubaland initiative. This involved creating a stable semi- autonomous buffer state along its border with Somalia. ${ }^{153}$ It was not a new endeavour as Wikileaks documents show that Kenya made several unsuccessful attempts to garner support for the initiative as early as 2009. ${ }^{154}$ Such attempts continued even after the beginning of Linda Nchi. Odinga specifically asked for the assistance of the EU and the US both in terms of troops and funds. ${ }^{155}$ However they refused because the Kenyan initiative clashed with their aim of building a strong central state in Somalia. ${ }^{156}$ Instead, Western assistance became conditional on Kenya joining AMISOM. ${ }^{157}$

With the cost of the invasion becoming unbearable, Kenya joined AMISOM in 2012 so that the expenses of keeping Kenyan troops in Somalia would be borne by the UN (through EU contributions). ${ }^{158}$ Thus, while Kenya applied legitimate and military power to influence members of the international

\footnotetext{
148 Kruger and Martin (2013)

149 Hansard (2012)

150 Tisdall, Simon (2011), 'Kenya's Intervention in Somalia is a Brave Move', The Guardian, 17 October; Otto (2012), p. 4

151 Menkhus (2012), p.7

152 BBC News (2012), 'Kenya's Raila Odinga Wants EU to Attack Somalia's Al- Shabaab Islamists', 12 June

153 BBC News (2011), 'Are Kenyans Seeking a Buffer Zone in Somalia?', 28 October

154 American Embassy, Djibouti (2009), 'Somalia: Kenyan Foreign Minister Pushes Lower Juba Initiative', Wikileaks Cable 09Djibouti1391_a, 10 December; US Embassy Nairobi (2010)

155 BBC News (2012)

156 Throup, David (2012), 'Kenya's Intervention in Somalia', Center For Strategic and International Studies, 16 February

157 BBC News (2012)

158 Hansard (2012)
} 
community, the international community also influenced Kenya through its financial power to coerce Kenya into joining AMISOM. As a result of Kenyan integration into AMISOM, resources that the UN allocated to the mission increased from US $\$ 300$ million to US $\$ 500$ million. ${ }^{159}$ So while Kenya did not obtain support for its unilateral actions, it did succeed in influencing the amount of resources allocated to terrestrial operations in Somalia. Yet there are indications that it did not abandon the idea of an autonomous Jubaland even when operating under the AMISOM umbrella.160 In fact, it kept supporting the Ras Kamboni militia group in southern Somalia. ${ }^{161}$ Ras Kamboni had similar objectives as Kenya in the sense that it wanted to defeat Al-Shabaab in Southern Somalia and set up an autonomous state in the Jubaland region. ${ }^{162}$ Consequently, Kenyan activities within AMISOM remained problematic especially for the TFG and fuelled a tense relationship between them. ${ }^{163}$

Therefore, for Kenya, piracy was a threat that had to be dealt with through land based measures that involved its own capacity building as well as intervening more directly in Somalia. To a large extent, piracy was just an addition to the existing list of threats that emanated from lawlessness in Somalia. Kenya was an assertive regional actor that pushed for responses that were more congruent with its experience of the problem. This led to a tense relationship with major international actors pursuing similar aims. Kenya led the prosecutorial aspect of the struggle. Yet, it did not hesitate to re-evaluate this response in the light of the lack of support from the international community, especially major extra-regional actors that failed to respect their capacity building commitments. Tensions also arose on the quality of the response on land in Somalia where Kenya looked beyond the TFG and worked with militia groups to stabilise Southern Somalia. A comparative analysis between EU and Kenyan responses to piracy further underlines those tensions.

\section{Comparative Analysis of the Two Contexts: A Low Degree of Mutuality?}

\footnotetext{
159 Miyandazi (2012)

160 Nzwili, Fredrick (2013), 'Is Kenya Birthing a New Country Named Jubaland?', The Christian Science Monitor, 08 July

161 Ibid.

162 Stanford University (2016), Mapping Militant Organizations: Ras Kamboni Movement, 12 January

163 Kelley, Kevin (2013), 'Somalia Opposes SH870m Funding for Kenya Navy', Daily Nation, 15 February
} 
This section juxtaposes EU and Kenyan responses to the common problem of piracy in order to assess the degree of mutuality that existed between them. On the surface, both EU and Kenya mutually desired an end to piracy, empowerment of regional actors to deal with threats in the maritime domain and stability in Somalia. Yet, underneath the surface of official discourses, interactions underpinning the construction of the responses indicate that there was a generally low degree of mutuality between EU and Kenyan responses to Somali piracy. Informed by their different appreciations of the situation, Kenya pursued a more creative response on land while the EU was much more creative in its naval responses. This led to different priorities which precluded the emergence of a strong partnership between regional and extra-regional actors at least in the case of the two major actors on which this study focuses.

As mentioned in the theoretical section above, defining the situation acts as a basis for organising collective actions. A comparison of the two definitions of the problem shows that there was more differences than similarities in the ways that the EU and Kenya experienced and articulated the impact of piracy. For both, piracy was a threat to their trade which depended heavily on the maritime realm. However, for the EU it also threatened its thriving blue economy and more specifically its shipping industry. Kenya did not share similar concerns about the shipping industry. Rather it was worried about the effects of the decline of cruise ship arrival on its tourism industry. However, both experiences point to the vitality of the maritime space which created a common need to combat piracy.

Both the EU and Kenya understood that the root of piracy was in the broader governance problem in Somalia. However, for the EU, first and foremost, it was its ships operating in the Indian Ocean that were directly threatened rather than its territorial integrity. In contrast, for Kenya, piracy had an important terrestrial dimension. Piracy (combined with Al-Shabaab) threatened the territorial integrity of Kenya especially when it became more difficult for pirates to operate in the high seas as a result of the success of the naval response. Even more pernicious, ransom money that flowed into Kenya artificially inflated the price of houses. These problems merged into existing dire refugee problems emanating from Somalia. Therefore, while these different experiences did not negate common objectives to deal with piracy and instability in Somalia, they created different needs and priorities. Thus, overall, there was generally a low degree of 'sense of shared 
feelings' 164 in the way that the problem was experienced even if the sources were similar.

Consequently, both EU and Kenya took leadership roles to initiate responses that reflected their individual experiences of the situation. As per the leadership as process framework, the roles of leader and follower changed hands depending on circumstances and the type of response being contemplated. Hence in the naval response, it was the EU that took the lead and initiated the process of developing mutuality with its members, non-EU states and industry to achieve the goal of providing security at sea. However, for SHADE, the EU took the role of follower as the initiative was US-led. In the judicial response, it was Kenya that took the lead by building relations with countries and organisations participating in the naval response. In this situation, actors like the US and EU had a followers' role. In contrast, Kenya took the follower's role in its judicial and maritime capacity building needs as actors like the EU and US had more power in those fields.

Even if they constituted two distinct responses, EU's naval actions and Kenya's judicial initiative were complementary as both sought to achieve the mutual purpose of combatting piracy. However, Kenya also envisaged its judicial response to contribute in dealing with terrestrial problems like instability in Somalia. The EU members were reluctant to prosecute suspected pirates in their own jurisdiction even if impunity threatened to undermine their naval response. Kenya responded to that need by accepting to take the responsibility for the prosecution. This became a crucial factor in explaining EU members' agreement to launch a naval operation under the banner of the EU. Thus, the very existence of EUNAVFOR depended on Kenya accepting to lead the judicial response. Similarly, Kenya's judicial response relied on the EU and the broader international community due to weaknesses in its judicial and penitentiary systems.

Kenya tried to mobilise the international community to achieve that purpose by signing MoUs with actors like the US and EU. The analysis of the Kenya-EU MoU shows that on that front there was high degree of mutuality, as the EU accepted to provide technical support, expertise, training and other assistance when so requested by Kenya. Consequently, it is safe to conclude that at least in the initial instances of the counter piracy operations, there was a high degree of mutuality between Kenya and global

164 Olonisakin (2017), p. 20 
actors like the EU both in terms of the purposes and the actions taken to achieve them.

This was short lived, however. An analysis of the implementation of the MoUs reveals a deep schism between Kenya's expectations and the intentions of the international community with evidence suggesting a lack of exchange of influence responsible for this situation. Pirates were delivered without proper evidence to assist prosecution and without consultations with the Kenyan authorities. Furthermore, pirates were brought in large numbers while, in Kenyan views, international assistance arrived slowly. Consequently, the Kenyan justice system was quickly overwhelmed which led to a thinning of that initially considerable degree of mutuality. It prompted Kenya to use threats (of ending to its role in the prosecution of pirates) in a bid to rekindle mutuality on capacity building. Yet the reaction of the $\mathrm{EU}$ and the broader international community again failed to meet Kenyan expectations.

A similar pattern of half-heartedness can be detected with the EU's intention to build maritime capacity in the region. On the surface, the lack of capacity in the region and the official willingness of the EU to help build regional capacity denote a high degree of mutuality between them. Mutuality in this aspect of the responses suggests the potential for the EU to empower regional states like Kenya to take leadership roles in providing maritime security in the Indian Ocean. Nevertheless, the EU's 'utterances' and the 'actions' again did not match on that occasion. The EUCAP NESTOR, at its very conception, came with a predetermined detailed list of capacitybuilding tasks that it would undertake. Apart from being understaffed and underfunded, the EUCAP NESTOR was controlled from Brussels and its projects reflected EU's concerns rather than those of the countries in the region. This lack of exchange of influence between EU and countries in the region (e.g. Kenya) means that no mutuality developed between them. The fact that Kenya refused to be part of this initiative even if it was a targeted country shows this absence of mutuality in capacity building in the maritime realm.

The above top-down approach contrasted sharply with the EU's way of building relationships for its naval response. It followed an interactive process, where its members could exchange influence with each other, both in the formulation and implementation of EUNAVFOR. Even if there were official leadership positions in EUNAVFOR (UK), its flat structure allowed for dialogue and the input of other EU members. Similar interactive processes were observed when EUNAVFOR developed mutuality with the 
shipping industry actors and actively engaged with them to improve their security to the extent that their interactions became institutionalised through the MSCHOA. Similarly, its interactions with other naval forces were institutionalised within SHADE. Overall, these interactions acted like synchronising devices that put and maintained these actors on the same wavelength. In other words, not only did the EU have strong mutuality with those actors, that mutuality was actively maintained in the face of changing circumstances through constant interactions.

\section{Looking in Different Directions in Somalia}

Both Kenya and the EU agreed that stabilising Somalia was the most viable long-term solution to the piracy problem. This involved dealing with several complex interconnected issues like combatting Al-Shabaab and engaging in statebuilding processes. However, the actors involved in stabilising Somalia had different interests and ideas on the solution to be pursued. More specifically, Kenya's urgent need to secure its border clashed with EU's more long-term statebuilding project. Unlike its eagerness to mount an interactive and creative naval response, the EU was much more conservative in engaging with lawlessness in Somalia as solutions revolved around the construction of a strong central state based in Mogadishu. In contrast, Kenya devised more creative solutions to bring stability along its border. Kenya's military intervention itself constituted a novel solution. More interestingly, its related project of creating a semi-autonomous state along the Kenya-Somalia border marked a break from its previously strong support for the TFG. In the language of leadership literature, the EU treated the stabilisation of Somalia as a tame problem and Kenya treated it as a wicked one. When a problem is defined as a tame one, the responses are drawn from known standard solutions (in that case building a strong centralised state) whereas when the same problem is defined as wicked, its perceived intractability force actors to look for novel solutions (in this case creating semi-autonomous regions). The clash between the two approaches produced a low degree of mutuality between them.

In pursuing these distinct trajectories, EU and Kenya developed mutuality with different actors in Somalia. Hence the EU developed a strong degree of mutuality with Somali's TFG because its idea of a western style centralised state aligned with TFG's endeavour to have a monopoly of power. It also strengthened its mutuality with the AU and the AMISOM forces as they were supposed to be pursuing similar centralised state endeavours. In contrast, Kenya's willingness to engage Somali militia groups involved a decentralisation of power. This automatically wore out its initial mutuality 
with the TFG as Kenya started to cultivate mutuality with militia groups like Ras Kamboni. Despite its attempts to persuade the EU and US about its Jubaland initiative, no mutuality developed between them on this project. Using its financial resources the EU tried to reassert its influence over Kenya and bring it back to the centralised state project. They have succeeded in form; but in substance Kenya still pursued its Jubaland project. Therefore the appearance of restored mutuality between Kenya and EU/TFG/AU is misleading as Kenya did not really abandon its buffer state project.

Therefore, through this comparison, one can safely point out that there was a generally low degree of mutuality between EU and Kenyan responses to piracy. The origin of this is in the way that the two actors experienced and articulated the situation, with Kenya placing more emphasis on the terrestrial aspect of the problem and responses thereof. The initial appearance of mutuality between EU's naval response and Kenya's judicial response quickly gave way to tensions especially over capacity building. EU's interactive and creative naval response was not replicated in regional capacity building measure and therefore failed to respond to the capacity building needs of Kenya. This low degree of mutuality was further confirmed by the radically different solutions that EU and Kenya pursued in trying to stabilise Somalia. The EU persisted with the traditional statebuilding solution whereas Kenya sought a more creative solution centred on the creation of semi-autonomous entities. Overall, the regional and the extra-regional responses did not really converge, at least in the cases of the EU and Kenya.

\section{Conclusion}

This paper has shown that there was a low degree of mutuality between EU and Kenya in their responses to Somali piracy between roughly 2008 and 2012. This was characterised by important differences in terms of priorities and approaches to the piracy problem which led to tensions between them and inhibited the formation of a strong common response. This position challenges the existing body of literature on the topic that obliterates the experiences and responses of regional states by general focus on western extra-regional actors (usually grouped under the term international community'). Even those who provided a regional perspective to the topic (such as Gottlieb) have portrayed a top-down process where the regional actors are mere respondents to the influence of the extra-regional actors. This body of literature also implicitly assumes a mutuality of interest between them. Thus, it incidentally provides a disempowering portrayal of 
regional actors and fails to capture the various ways that regional states initiated responses based on their own experience of the problem.

Using the leadership as a process lens, this paper provided a more complex picture of the responses to Somali pirates by factoring Kenyan experiences and responses into the equation and comparing them with those of the EU. Leadership as process provides an analytical framework that helps incorporate the ways that the impact of piracy was felt within a given context into the analysis of the responses. It draws attention on interactions which when applied to this study reveals the tensions and convergences between actors participating in counterpiracy. On paper, the EU and Kenyan responses converged to a large degree, but an analysis of interactions ultimately revealed a low degree of mutuality between them.

The EU mounted a comprehensive programme for dealing with piracy. However, an analysis of the interactions showed that it did not approach the three main components with the same urgency, political will and intentions. Due to the directness of the piracy threat to its thriving shipping industry, it mounted a strong naval response and in the process developed interactive relationships with other naval forces and the shipping industry. Its interactions with the shipping industry led to the formulation of innovative measures like the MSCHOA. In contrast, EU's capacity building endeavour in the region followed a top-down approach which failed to respond to the needs of countries like Kenya. Therefore it had little effect on the capacity of countries like Kenya to respond to maritime security threats like piracy. The same lack of interaction and creativity characterised its stabilisation programme in Somalia where the focus on the formation of a central state around the TFG led it to ignore other security actors that are not in official leadership positions. Consequently, it did not have any marked effect on the stabilisation of Somalia.

Through its utterances and actions, Kenya assumed power to define the situation according to its own experience and emphasised a land response which would not only deal with piracy but also other threats emanating from Somalia. At first, its judicial response fed into the EU's naval response in the sense that they both combined to deter piracy. Yet it was subject to the EU and other members of the international community contributing to its capacity building needs to carry out its judicial functions efficiently. Again, on paper, there was mutuality between them, but subsequent interactions revealed serious discrepancies in the expectations and intentions of both actors. When members of the international community failed to provide for these needs, Kenya reconsidered its role in the 
prosecution of pirates. Furthermore, in the absence of a strong response on land in Somalia, Kenya used its own military power to start a military operation in Somalia. It also showed willingness to try solutions other than the creation of a central state in Somalia. Therefore, instead of merely feeding into the international community's responses, Kenya departed from them and pursued solutions that were more reflective of its experiences of the situation.

Overall, beyond bringing analysis of regional states into the counterpiracy picture, this paper has contributed to Burn's endeavour to lift leadership studies out of the 'anecdotal and the eulogistic.' By applying leadership theory to the international realm and non-human entities (states and international organisations) it has shown that leadership as process has wider application than the western corporate world. The limitation of this paper, however, is that it has analysed interactions from a document analysis of several written sources only. They do not provide all the details of the interactive processes surrounding counterpiracy. Other methods, such as interviews, can help acquire finer details of interactions among the actors and can be used to supplement and cross-check information gathered from written sources. Furthermore, it would also be interesting to undertake similar studies for other regional actors such as the Seychelles to see if this paper's findings can be generalised to the whole East African region.

*Linganaden Murday is a lecturer in the Department of History and Political Science at the University of Mauritius (UOM).

\section{BIBLIOGRAPHY}

American Embassy, Djibouti (2009), 'Somalia: Kenyan Foreign Minister Pushes Lower Juba Initiative', Wikileaks Cable 09Djibouti1391_a, 10 December. Available at: https://wikileaks.org/plusd/cables/09DJIBOUTI1391 a.html(Accessed 26 July 2018)

AMISOM (2018), Frequently Asked Questions. Available at: http://amisomau.org/frequently-asked-questions/ (Accessed 12 July 2018)

Axe, David (2008), 'Somali Pirates Face Justice, Finally', Wired, 15 December. Available at: https://www.wired.com/2008/12/pirates-haveth/(15 July 2018) 
Bachmann, Jan (2012), 'Kenya and International Security: Enabling Globalisation, Stabilising 'Stateness', and Deploying Enforcement', Globalizations, 9(1), pp. 125-143

BBC News (2010), 'Kenya Opens Fast-Track Piracy Court in Mombasa', 24 June. Available at: https://www.bbc.com/news/10401413 (Accessed 20 June 2018)

BBC News (2011), 'Are Kenyans Seeking a Buffer Zone in Somalia?', 28 October. Available at: https://www.bbc.co.uk/news/world-africa15499534 (Accessed 17 August 2018)

BBC News (2012), 'Kenya's Raila Odinga Wants EU to Attack Somalia's AlShabaab Islamists', 12 June. Available at:

https://www.bbc.co.uk/news/world-africa-18406385 (Accessed 21 July 2018)

Beja, Patrick (2015), 'Kenya Poised to Attract Global Shipping Lines With Establishment of List', Standard Digital, 28 September. Available at: https://www.standardmedia.co.ke/business/article/2000177875/kenyapoised-to-attract-global-shipping-lines-with-establishment-of-list (Accessed 03 August 2018)

Brunnstrom, David (2008), 'EU Launches Somalia Anti-Piracy Operation', Reuters, 08 December. Available at: https://www.reuters.com/article/ussomalia-pirates-idUSTRE4B74YF20081208 (12 August 2018)

Bueger, Christian (2013), 'In Search for a Mission? The EU's Regional Training Mission EUCAP NESTOR', Piracy-Studies.Org, 18 October. Available at: http://piracy-studies.org/in-search-for-a-mission-the-eusregional-training-mission-eucap-nestor (Accessed 15 August 2018)

Bureau of Democracy, Human Rights, and Labor (2009), Kenya: 2008 Country Reports on Human Rights Practices, US Department of State, 25 February. Available at: https://www.state.gov/j/drl/rls/hrrpt/2008/af/119007.htm (Accessed 10 July 2018)

Burns, James Macgregor (2012), Leadership (New York: Open Road Integrated Media) 
Leadership and Developing Societies

Vol 3 No1, pp. 33-69

DOI: https://doi.org/10.47697/lds.3436101

Burt, Alistair (2013), Speech: International Action Against Piracy, 21

January. Available at:

https://www.gov.uk/government/speeches/international-action-againstpiracy (Accessed 07 August 2018)

Council Decision 2010/96/CFSP, 15 February 2010. Available at:

http://www.europarl.europa.eu/meetdocs/2009 2014/documents/sede/ $\mathrm{dv} /$ sede030510councildeceutmsomalia /sede030510councildeceutmsom alia en.pdf(Accessed 17 August 2018)

Council Decision 2012/389/CFSP, 16 July 2012. Available at: http://www.europarl.europa.eu/meetdocs/2009 2014/documents/sede/ $\mathrm{dv} /$ sede121112cd389/sede121112cd389 en.pdf(Accessed 20 August 2018)

Creswell, John (2014), Research Design: Qualitative, Quantitative and Mixed Methods Approaches (London: Sage)

Damanaki, Maria (2013), Speech: Maritime Piracy: Continuing the Fight, 23 January. Available at: http://europa.eu/rapid/press-release SPEECH-1349 en.htm?locale=en (Accessed 07August 2018)

Daniels, Christopher (2012), Somali Piracy and Terrorism in the Horn of Africa (Lanham: The Scarecrow Press)

Eckhardt, Karl (2012), 'Deterring Piracy through Prosecution', in University of Washington (2012), Task Force 2012: The Challenge of Piracy Off the Horn of Africa (Seattle: University of Washington)

Ejdus, Filip (2017), “Here is Your Mission, Now Own It!” The Rhetoric and Practice of Local Ownership in EU Interventions', European Security, 26(4), pp.461-484

European Community Shipowners's Associations (N.d), The European Shipping Industry in a Nutshell, (Brussel: ECSA). Available at: https://www.ecsa.eu/sites/default/files/publications/ECSA brochure 0.p $\underline{\text { df }}$ (Accessed 02 August 2018)

EU NAVFOR Somalia (2018), 'Mandate', European Union External Action. Available at: http://eunavfor.eu/mission/ (Accessed 05 August 2018) 
EUR-Lex (2009), Exchange of Letters Between the European Union and the Government of Kenya, Document 22009A0325(01). Available at:

https://eur-lex.europa.eu/legalcontent/EN/TXT/?uri=CELEX\%3A22009A0325\%2801\%29 (Accessed 10 July 2018)

European Scrutiny Committee (2015a), Regional Maritime Capacity Building in the Horn of Africa (EUCAP NESTOR), 14 October. Available at: https://publications.parliament.uk/pa/cm201516/cmselect/cmeuleg/34 2-v/34230.htm\#note147 (Accessed 15 August 2018)

European Scrutiny Committee (2015b), EU Military Mission to Contribute to the Training of Somali Security Forces (EUTM), 25 February. Available at: https://publications.parliament.uk/pa/cm201415/cmselect/cmeuleg/21 9-xxxiii/21911.htm (Accessed 20 August 2018)

European Union External Action (2010), 'Piracy Threat and Merchant Industry', 14 October. Available at: http://eunavfor.eu/piracy-threat-andmerchant-industry /(Accessed 27August 2018)

European Union External Action (2018a), MSCHOA. Available at: http://eunavfor.eu/mschoa/_(Accessed 01 August 2018)

European Union External Action (2018b), 'EU NAVFOR Atalanta: 10 Years of Fighting Piracy in Somalia', Press Release, 08 December available at https://eeas.europa.eu/headquarters/headquarters-

homepage/55058/eu-navfor-atalanta-10-years-fighting-piracysomalia en (Accessed 03 March 2019)

French, John and Raven Bertram (1959), The Bases of Social Power, in D. Cartwright (Ed.), Studies in Social Power (Ann Arbor: Institute for Social Research; University of Michigan), pp.259-269

Gettleman, Jeffrey (2011), 'Kenyan Forces Enter Somalia to Battle Militants', The New York Times, 16 October. Available at: https://www.nytimes.com/2011/10/17/world/africa/kenyan-forcesenter-somalia-to-battle-shabab.html (Accessed 23 July 2018)

Gathii, James Thuo (2010), 'Kenya's Piracy Prosecutions', The American Journal of International Law, 104(3), pp.416-436 
Leadership and Developing Societies

Vol 3 No1, pp. 33-69

DOI: https://doi.org/10.47697/lds.3436101

Ghosh, P.K. (2016), 'Shared Awareness and Deconfliction Initiative', IndoPacific Defense Forum, 23 February. Available at: http://apdf-

magazine.com/shared-awareness-and-deconfliction-initiative/ (Accessed 13 August 2018)

Gottlieb, Yaron (2015), 'Responding to Maritime Piracy: The Regional Approach', University of Sanfranscisco Maritime Law Journal, 28 (1), pp. 134

Grint, Keith (2008), Leadership, Management and Command: Rethink D-Day (New York: Palgrave Macmillan)

Grint (2010), Leadership: A Very Short Introduction (New York: Oxford University Press)

Gunther, Enrico, (2015), The European Union's Response to Piracy: Are the Lessons Learned in the Horn of Africa a Model for the Gulf of Guinea?, EU Diplomacy Paper 07/2015. Available at: http://aei.pitt.edu/70369/1/edp 72015 gunther.pdf(Accessed 22 August 2018)

Hansard (2009a), Kenya Parliamentary Debates 3692, 11 November. Available at:

http://info.mzalendo.com/hansard/sitting/national assembly/2009-1111-09-00-00\#entry-123250 (Accessed 12 July 2018)

Hansard (2009b), Kenya Parliamentary Debates 3674, 10 November. Available at:

http://info.mzalendo.com/hansard/sitting/national assembly/2009-1110-14-30-00 (Accessed 15 July 2018)

Hansard (2009c), Kenya Parliamentary Debates 3695, 11 November. Available at: http://info.mzalendo.com/hansard/sitting/national assembly/2009-1111-09-00-00\#entry-123250_(Accessed 16 July 2018)

Hansard (2010), Kenya National Assembly Official Report, 01 December. Available at:

http://info.mzalendo.com/hansard/sitting/national assembly/2010-1201-14-30-00\#entry-74230 (Accessed 16 July 2018) 
Leadership and Developing Societies

Vol 3 No1, pp. 33-69

DOI: https://doi.org/10.47697/lds.3436101

Hansard (2012), Kenya National Assembly: Official Report, 23 May.

Available at:

http://info.mzalendo.com/hansard/sitting/national assembly/2012-0523-14-30-00\#entry-287386 (Accessed 12 July 2018)

Homan, Kees and Kamerling, Susanne (2010) 'Operational Challenges to Counterpiracy Operations Off the Coast of Somalia', in Van Ginkel, Bibi and Van der Putten, Frans-Paul (Eds) (2010), The International Response to Somali Piracy: Challenges and Opportunities, (Leiden: Martinus Nijhoff Publishers)

House of Lords (2010), Combating Somali Piracy: The EU's Naval Operation Atalanta, European Union Committee, $12^{\text {th }}$ Report of Session 2009-10

House of Lords (2012), Turning the Tide on Piracy, Building Somalia's Future: Follow-up Report on the EU's Operation Atalanta and Beyond, European Union Committee: $3^{\text {rd }}$ Report of Session 2012-13

Kamal-Deen, Ali (2015), Maritime Security Cooperation in the Gulf of Guinea: Prospects and Challenges (Leiden: Brill Nijhoff)

Kagwe, Winfred and Kikhara, Githua (2011), 'Piracy Shoots Down Cruise Ships Numbers', Daily Nation, 19 January. Available at: https://www.nation.co.ke/business/Piracy-shoots-down-cruise-shipsnumbers/996-1092248-taewbpz/index.html (Accessed 07 July 2018)

Kelley, Kevin (2013), 'Somalia Opposes SH870m Funding for Kenya Navy', Daily Nation, 15 February. Available at:

https://www.nation.co.ke/News/Somalia-strongly-opposes-funding-forAmisom-naval-force/-/1056/1694654/-/10xulf7z/-/index.htm (Accessed 10 July 2018)

Khalif, Abdul Kadir and Mwangi, Nyassy Daniel (2011), 'Fury as Gang Abducts Fishermen in Malindi', Daily Nation, 20 November. Available at: https://www.nation.co.ke/news/Fury-as-gang-abducts-fishermen-inMalindi/1056-1276480-kri97xz/index.html (Accessed 23 June 2018)

Kimenyi, Mwangi and Kibe, Josephine (2014), 'Africa's Powerhouse', Brookings, 06 January. Available at: https://www.brookings.edu/opinions/africas-powerhouse/ (Accessed 24 June 2018)

Kraska, James and Wilson, Brian (2011), 'Combatting Piracy in International Waters', World Policy, 23 February. Available at 
Leadership and Developing Societies

Vol 3 No1, pp. 33-69

DOI: https://doi.org/10.47697/lds.3436101

https://worldpolicy.org/2011/02/23/combatting-piracy-in-

international-waters/ (Accessed 27 March 2019)

Kruger, Anton and Martin, Guy (2013), 'Kenya Defence Forces',

DefenceWeb, 09 July. Available at:

http://www.defenceweb.co.za/index.php?option=com content\&view=arti cle\&id=31108:kenya-defence-forces\&catid=119: african-militaries (Accessed 24 June 2018)

Lakshmi, Aiswarya (2015), 'Kenya to Focus on Maritime Safety, Security', MarineLink, 24 February. Available at:

https://www.marinelink.com/news/maritime-security-safety386419

(Accessed 23 June 2018)

Leposo, Lillian (2010), 'Kenya Ends Agreement with EU to Prosecute Suspected Somali Pirates', CNN, 04 October. Available at:

http://edition.cnn.com/2010/WORLD/africa/10/04/kenya.eu.pirates/ind ex.html (Accessed 06 July 2018)

Lidington, David (2012), Speech: EU Common Security and Defence Policy: The UK Perspective, 27 June. Available at:

https://www.gov.uk/government/speeches/eu-common-security-anddefence-policy-the-uk-perspective (Accessed 17 August 2018)

Mayoyo, Patrick and Barasa, Lucas (2008), 'Piracy Off Somali Coast a Growing Global Headache', Daily Nation, 22 November. Available at: https://www.nation.co.ke/news/1056-493950-kmmy0uz/index.html (Accessed 23 June 2018)

Menkhus, Ken (2012), After the Kenyan Intervention in Somalia, The Enough Project, January

Menya, Walter (2010), 'Why Kenya Broke Deal on Piracy Trials', Daily Nation, 9 October. Available at: https://www.nation.co.ke/news/WhyKenya-broke-deal-on-piracy-trials-/1056-1029504-emxyij/index.html (Accessed 04 July 2018)

Miyandazi, Luckystar (2012), 'Kenya's Military Intervention in Somalia', Accord, 11 November. Available at: http://www.accord.org.za/publication/kenya-s-military-intervention-insomalia/ (Accessed 07 July 2018)

MSCHOA (2016), About MSCHOA and OP ATALANTA. Available at: http://www.mschoa.org/on-shore/about-us (Accessed 03 August 2018) 
Leadership and Developing Societies

Vol 3 No1, pp. 33-69

DOI: https://doi.org/10.47697/lds.3436101

Muratore, Andrew (2010), 'EU-NATO Co-operation and the Pirates of the Gulf of Aden', Australian Journal of Maritime and Ocean Affairs, 2(3), pp.90102

Murphy, Albert (1941), 'A Study of the Leadership Process', American Sociological Review, 6(5), pp.674-687

Northouse, Peter (2013), Leadership: Theory and Practice (London: Sage)

Nzwili, Fredrick (2013), 'Is Kenya Birthing a New Country Named Jubaland?', The Christian Science Monitor, 08 July. Available at: https://www.csmonitor.com/World/Africa/2013/0708/Is-Kenyabirthing-a-new-country-named-Jubaland (Accessed 01 August 2018)

Oceans Beyond Piracy (2014), The State of Maritime Piracy 2014: Assessing the Economic and Human Cost, (Denver: One Earth Future Foundation)

Oceans Beyond Piracy (N.d.), Shared Awareness and Deconfliction.

Available at: http://oceansbeyondpiracy.org/matrix/shared-awarenessand-deconfliction-shade (Accessed 06August 2018)

Oksamytna, Kseniya (2011a), 'The European Union Training Mission in Somalia: lessons Learnt for EU Security Sector Reform', IAI Working Papers 11, 16 June. Available at: http://www.cosv.org/download/centrodocumentazione/iaiwp1116.pdf (Accessed 15 August 2018)

Oksamytna, Kseniya (2011b), 'The European Union Training Mission in Somalia and the Limits of Liberal Peacebuilding: Can EUTM Contribute to Sustainable and Inclusive Peace?', The International Spectator, 46(4), pp.97-113

Olonisakin, 'Funmi (2017), 'Towards Re-conceptualising Leadership for Sustainable Peace', Leadership and Developing Societies, 2(1), pp.1-30

Otto, Lisa (2012), Situation Report: Kenya and the Pest of Piracy, Institute for Security Studies, 22 February. Available at:

https://www.files.ethz.ch/isn/138786/22Feb12Kenya.pdf(Accessed 26 June 2018)

Pierce, Jon and Newstrom, John (2011), Leaders and the Leadership Process (New York: McGrawhill)

Raven, Bertram (1993), 'The Bases of Power: Origins and Recent Developments, Journal of Social Issues, 49(4), pp.227-251 
Riddervold, Marianne (2014), 'New Threats- Different Response: EU and NATO and Somali Piracy', European Security, 23(4), pp. 546-564

Rost, Joseph (1993), Leadership for the Twenty-First Century (London: Praeger)

Saul, Jonathan and Reed, Camila (2011), 'Shabaab- Somali Pirate Links Growing: UN Adviser', Reuters, 20 October. Available at: https://www.reuters.com/article/ozatp-somalia-shabaab-piratesidAFJOE79J0G620111020 (Accessed 02 July 2018)

Smircich, Linda and Morgan, Gareth (1982), 'Leadership: The Management of Meaning', The Journal of Applied Behavioral Science, 18(3), pp.257-273

Smith, Michael (2017), Europe's Common Security and Defence Policy: Capacity-Building, Experiential Learning, and Institutional Change, (Cambridge: Cambridge University Press), Chapter 6. Available at: https://www.cambridge.org/core/books/europes-common-security-anddefence-policy/eu-as-a-maritime-actor-eunavforsomalia/D530A23AEAD23F4341DB546AD8E1A64B/core-reader\#FN-fn$\underline{540}$ (Accessed 16 August 2018)

Solana, Javier (2009a), 'Mobilise Now to Stabilise Somalia', The Guardian, 12 August. Available at: https://www.theguardian.com/commentisfree/2009/aug/12/stabilisesomalia-poverty-piracy (Accessed 04 August 2018)

Solana, Javier (2009b), Informal Meeting of the Defence Ministers- Remark by Javier Solana, Prague, 12-13 March 2009. Available at: https://www.iss.europa.eu/sites/default/files/EUISSFiles/Core Documen ts Vol X eng 0.pdf (Accessed 18 August 2018)

Stanford University (2016), Mapping Militant Organizations: Ras Kamboni Movement, 12 January. Available at http://web.stanford.edu/group/mappingmilitants/cgibin/groups/view/489 (Accessed 07 April 2019)

Stremlau, Nicole (2019), 'Governance Without Government in the Somali Territories', Columbia Journal of International Affairs, 09 January. Available at https://jia.sipa.columbia.edu/governance-without-government-somaliterritories (Accessed 27 March 2019) 
Leadership and Developing Societies

Vol 3 No1, pp. 33-69

DOI: https://doi.org/10.47697/lds.3436101

The European Commission (2010), Commission Recommendation of 11 March 2010 on Measures for Self-Protection and the Prevention of Piracy and Armed Robbery Against Ships, 2010/159/EU

The World Bank (2013), The Pirates of Somalia: Ending the Threat, Rebuilding a Nation, (Washington: The World Bank)

Throup, David (2012), 'Kenya's Intervention in Somalia', Center For Strategic and International Studies, 16 February. Available at:

https://www.csis.org/analysis/kenya\%E2\%80\%99s-interventionsomalia (Accessed 06 July 2018)

Tisdall, Simon (2011), 'Kenya's Intervention in Somalia is a Brave Move', The Guardian, 17 October. Available at:

https://www.theguardian.com/commentisfree/2011/oct/17/kenyaintervention-somalia (Accessed 28 June 2018)

UNSC (2008), Resolution 1851, 16 December. Available at: http://www.un.org/en/ga/search/view doc.asp?symbol=S/RES/1851(20 08) (Accessed 12 July 2018)

UNSC (2010), Report of the Monitoring Group on Somalia and Eritrea Pursuant to Security Council Resolution 1916. Available at: http://www.un.org/ga/search/view doc.asp?symbol=S/2011/433 (Accessed 12 June 2018)

UNSC (2011), Report of the Special Adviser to the Secretary-General on Legal Issues Related to Piracy off the Coast of Somalia, 24 January. Available at: http://repository.un.org/bitstream/handle/11176/14957/S 2011 30EN.pdf?sequence $=3$ \&isAllowed $=y$ (Accessed 17 June 2018)

US Embassy Nairobi (2009a), 'Update on Kenyan Piracy Prosecutions', WikiLeaks cable 09NAIROBI1527_a 16 July. Available at:

https://wikileaks.org/plusd/cables/09NAIROBI1527 a.html (Accessed 27 July 2018)

US Embassy Nairobi (2009b), 'Kenya Threatens End to Piracy Prosecutions', WikiLeaks cable 09NAIROBI2016_a dated 24 September. Available at: https://wikileaks.org/plusd/cables/09NAIROBI2016 a.html (Accessed 25 July 2018)

US Embassy Nairobi (2010), 'ASD Vershbow Visit Highlights Regional Security Issues', Wikileaks cable 10NAIROBI159_a, 11 February. Available 
at: https://wikileaks.org/plusd/cables/10NAIROBI159 a.html (Accessed 18 July 2018)

US Mission to European Union (2009), 'EU Developing Comprehensive Approach to Fighting Piracy', Wikileaks cable 09Brussels878_a, 25 June. Available at: https://wikileaks.org/plusd/cables/09BRUSSELS878 a.html (Accessed 03 August 2018)

US Secretary of State (2008), 'Progress on US Counter-Piracy Agenda at International Piracy Conference', WikiLeaks Cable 08STATE134960_a dated 28 December. Available at:

https://wikileaks.org/plusd/cables/08STATE134960 a.html (Accessed 13 July 2018)

Van Ginkel, Bibi and Van der Putten, Frans-Paul (2010), 'Introduction: The International Responses to Somali Piracy', in Van Ginkel, Bibi and Van der Putten, Frans-Paul (Eds) (2010), The International Response to Somali Piracy: Challenges and Opportunities, (Leiden: Martinus Nijhoff Publishers)

Vines, Alex (2010), 'Rhetoric from Brussels and Reality on the Ground: the EU and Security in Africa', International Affairs, 86(5), pp.1091-1108

Williams, Paul (2016), 'AMISOM Under Review', The RUSI Journal, 161(1), pp.40-49

Willsher, Kim (2011), 'Kidnapped French Woman Taken to Somalia by Pirates After Sea Battle', The Guardian, 01 October. Available at: https://www.theguardian.com/world/2011/oct/02/kidnapped-frenchwoman-somalia-pirates (Accessed 07 July 2018)

World Maritime News (2018), 'EU's Anti-Piracy Operation Gets Extension', 03 August. Available at https://worldmaritimenews.com/archives/258294/eus-anti-piracyoperation-gets-extension/ 